\title{
Analyzing the Compensation and Competence on Senior High Schools Teacher's Performance through the Mediating Role of Job Motivation
}

\author{
Faisal Matriadi \\ Department of Management \\ Universitas Malikussaleh \\ Aceh, Indonesia \\ faisalmatriadi@gmail.com
}

\author{
Ritha F. Dalimunthe \\ Department of Management \\ Universitas Sumatera Utara \\ Medan, Indonesia \\ rithadalimunthe@gmail.com
}

\begin{abstract}
Service today's increasingly competitive education - It is encouraging schools at this time to further improve its performance. One attempt to do is to improve the performance of teachers and increase job motivation. The purpose of this study was to analyze the effect of compensation and competence on job motivation and senior high schools teacher performance in Lhokseumawe. The population data collected in the study were all accounts totaling 351 teachers from seven senior high schools that made the object of research. Seven hypotheses for direct and mediating effect were formulated to be tested using PLS (Partial Least Square) analyses through SEM-PLS software with WarpPLS 3.0. The results show that compensation and competence are significantly influence toward job motivation. Results also showed that compensation, competence, and job motivation are significantly influence toward teacher performance. Meanwhile, job motivation support mediates the relationship between compensation and competence to senior high schools teacher performance in Lhokseumawe.
\end{abstract}

Keywords - compensation; competence; job motivation; teacher performance

\section{INTRODUCTION}

Job performance of employees plays a crucial factor in determining an organization performance since highly performing individuals will be able to assist organization to achieve its strategic aims thus sustaining the organization competitive advantage [1].

Job performance has always been the central issue in research work in the field of human resource and organizational behavior [2]. Researchers are constantly trying to come up with the best variables that can reliably and accurately explain and forecast future job performance of all organizational employees [3],[4]. Over the years, a substantial amount of research on job performance has been contemplated not only by scholars in the human resource and organizational behavior, but also, those in the applied psychology, adult learning, management, and education areas as well. Although performance-related research has been extensively covered, performance is proven to be dynamic in nature [5]. Thus, there are always meaningful variations or diversification that can trigger new research questions pertaining to job performance.
In short, quality and high-performing teachers are very crucial [6]; thus, studying individual and organizational factors which contribute towards job performance among teachers is considered as not only theoretically significant and but practically in line with the current national aspirations to upgrade teacher quality and performance. In addition, in order to improve teacher quality and performance, there must be improvement made to the human resource practice such as compensation, competence and job motivation [6]. Research on Performance-related studies have been dealt in depth in the business and industrial setting. It is worth to investigate if some of the concepts used in the business and industrial setting could also be applied to in the educational setting, to explain teachers' performance.

The significance of this present research can be divided into two perspectives. Firstly, the significance of this study can be seen from the theoretical perspective. Even though there were many research interest on the determinants of job performance (e.g. [7],[8], [9],[10],[11],[12],[13],[14]), most of them were conducted abroad, and thus lack of evidence exist to understand the job performance of Senior High Schools teachers in the Indonesian context.

Furthermore, lack of attempt was made in the study of job performance which focus on teachers working in the Senior High Schools as many previous studies regarded all employees of the educations as the same regardless of the sectors they were in which had been proven to be different [15],[16]. This condition had therefore illuminated a significant gap in the past literature on Indonesian education that tend to focus on overall sectoral problems and organizational level problems rather than from the individual level problems in respect to job performance. Thus, the present study may contribute to the existing literatures on education in Indonesia specifically in the context of education, which has not received much attention. At the same time, it is hopeful that this study will be able to add on to the present literatures of education by highlighting the issues faced by education sector from the teachers' perspectives that often been overshadowed by many researches on organization level performance. 
Secondly, from the applied significance perspective, this study is able to provide better understanding on the performance of teacher in Senior High Schools sector within the education context. The knowledge obtained can assist teacher $\mathrm{s}$ in developing strategies that may help to motivate teachers to perform better. In addition, this research is an opportunity for education to view the present problems faced by the education in relation to skill shortages and lack of productivity from the perspective of teachers. Therefore, it is also hope for these problems to be resolved through better understanding of the factors that can affect teachers' job performance, which in turns may help to overcome the ongoing human resources issues of the education.

Contrary to measures of job performance in studies in business and industrial context, the construct of teacher job performance is usually referred to as uni dimensional in many research work involving teachers. The measure of teacher performance usually concentrates on the ratings of a teacher's teaching skill, as the sole dimension [17],[18],[19]. Some authors measure teachers' organizational citizenship behavior as a form of performance measure [20],[21]. However, more recently, there has been attempts to measure performance multidimensionally (e.g., [22],[23],[24]).

In addition, employees in a service setting also need to possess the right competency in order to be effective in their job performance. According to [25], it is necessary for service workers to be skilled and trained in order to deliver effective service. Some examples of competencies that are necessary for service employees consist of friendliness, concern, insight, communicative and adaptive were noted [26],[27]. Previous studies (e.g. [28],[29],[30],[31]) on the relationship between competency and job performance were conducted abroad while studies on competency (e.g. [32],[33],[34]) focused on issues either related to the entrepreneurs' or the public sector employees.

Therefore, the present study aims to advance the researcher understanding of the relationship between compensation, competence, job motivation and teacher performance in Senior High Schools in Indonesia's context.

\section{BASIC THEORY AND HYPOTHESES DEVELOPMENT}

\section{A. Performance}

Generally, performance is a measurement or indicator for evaluation and assessment of individuals, group, firm and organizations. It reveals the strength and weakness of what we want to measure. Teachers play key roles in the education process. This could be because they provide professional touch in the profession. People see them as persons having the adequate knowledge to impart knowledge to people. In examining what teacher's role should be, [35] noted that there has been little-sustained analysis of the role of the teacher. In the academic domain, it has been noted that a good and well systematic performance measurement system should be designed in such a way that it will give room for collecting, analyzing and reporting data and information which are related to the performance of the academic departments [36]. This has led to some major development and significant continuities with performance measures in educational organizations.

Accordingly, [37] reported that there are about four groups of performance indicators which are as follows; internal performance indicator, indicators of operational performance, external performance indicator and last but not the least, research indicator performance. In another dimension, [38] noted that performance measure provides information relating to following; planning, investigating, coordinating, evaluating, supervising, staffing, negotiating, representing and your or firm or organization overall performance. These indicators are well related to both individual and organizational performance, and deeply related to the human resources domain. [39] provided performance indicators such as efficiency, internal liquidity, strategic human resources effectiveness, profitability, and leverage.

With respect to teacher performance, it can be defined as the ability in planning, implementing, and evaluating the teaching-learning process [40]. It involves teacher's efficacy in doing or completing a job. On like other aspects of performance, teacher performance has been measured using different dimensions. For instance, [41] in investigating the teacher performance adopted a performance measure that assessed the overall performance rating of the teacher by using two dimensions of; effective and best educator. Similarly, [42] in measuring the performance of the lecturers in the university adopted an objective approach.

There seems to be no end to what performance measure should be among authors and researchers, however, whatever the performance measurement, a researcher should be able to justify which performance measure he or she adopts in the course of his/her research [43]. Based on the insight derived above, this study operationalized teacher performance as: effectiveness, professionalism and overall performance.

\section{B. Job Motivation}

Motivated employees are one of the criteria that contribute to organizational success. Motivated employees will concentrate their effort and direction towards the achievement of organization's goal [44]. Motivation is very important because it can drive an individual to work hard or perform well in their work. According to [45], employee motivation toward works refers to the way employee does their work and expresses it by their service or work to the organization. Employees that have high motivation will be more loyal and dedicated to their job and always perform for the best interest of the organization. Previous studies stated that employee motivation do have a positive relationship with organizational performance. [46] study showed that there are relationships between employee motivation and the organizational performance. The study reveals that motivated workers in an organization has a significant influence on their performance. This is in line with equity theory which emphasizes that fairness in the remuneration package tends to produce higher performance from workers.

Other researchers like [47] identified that employee motivation has significant relationship with performance where the motivational factors inside an employee will 
enhance their productivity in organization. Other than that, [48] also found that there is positive relationship between employee motivation and organizational performance. The study shows that firm's performance increase when the employee motivation increases. Financial rewards actually influence the employee performance and boost their motivation. Hence, financially satisfied workers contribute to firm's performance [44]. In contrast, there is also study that says payment does not influence or improve employee motivation but non-financial factors like non-financial rewards, social recognition, and performance feedback actually give positive influence to employee motivation [49].

\section{Compensation}

This study focuses on the relationship between compensation, competence, job motivation and teachers performance in Senior High Schools in Aceh Province. There are many past studies [50],[51],[52],[53],[54],[55] that have been conducted on employees' performance. [56] claim that reward package as compensation can influence the employee's performance in their work. According to them, compensation system gives an impact to employee performance by improve employee knowledge, skill and abilities to achieve to organization goals. [51] agree that compensation gives an impact to employee performance, the compensation gives indirect effect to employee in-role and extra-role behavior so it will improve employee in-role performance without sacrificing extra-role performance. [57] also agree that compensation practices play an important role in improving employee performance and to achieve organizational goal.

As mentioned before, numerous previous studies found that employees' performance is associated to the compensation [58],[59],[60],[61]. Nevertheless, these researches are predominantly western oriented and highlighted cases in the context of western environment which are not reflected the Asian countries especially Indonesia. In addition, less attention also has been given in looking the best practice of compensation system in the field of education. As this study refers to the Indonesia's context, it is key important to understand the compensation system in Senior High Schools and its relationship with the employee performance specifically on productivity, job quality and job accomplishment in the Indonesian private tertiary education institution.

\section{Competence}

Generally, teaching has been considered as one of the most interesting challenging professions in human endeavor [62]. Probably because it deals mainly with human beings. People need to teach others in order for them to learn and be educated, while those who teach others must possess the right competence and compensation to enable them impart knowledge and education to the people or learners as whatever they teach has a durable effect in the lives of the people they teach.

The term competence has been widely used in various contexts by several authors [63],[64]. Hence, the term has several definitions. For instance, it has been used in the context of teacher education and job performance. By simple description, competence is a prerequisite for the competencybased-teacher education that comprises of skills, value, and knowledge which professional teachers should exhibit for effective and successful completion of the teacher education programme [65].

The importance of competence in teaching profession cannot be underestimated. According to [65], it offers guidelines for success and assists in assessing measurable gaps that will be directly aligned with the work results required of the job as well as with the goals of the organization.

Many empirical studies (e.g. [64],[66] have been conducted with respect to teacher competence and performance. The competence model provided by [67] demonstrated that a teacher's performance depends on the teachers' knowledge, (comprised of subject matter and general pedagogy), which is directly linked to the teachers' competencies, characteristics, and attitudes.

The Competency-Based Education Theory which is very popular in the education domain argued on the need for teachers to possess the right attributes and characteristics for better performance [68]. Thus, the theory argued on the importance of individual characteristics that will aid teacher performance. Utilising this theory, [68] argued that activities of teachers as well as their attributes will be more helpful in training teachers than individual opinion information. Therefore, they contended that teachers' characteristics play indispensable role in the teachers' effectiveness and performance. [69] noted that teachers' competencies are based on competency-based teacher education theory which are connected to all areas of performance which performance can be assessed.

Furthermore, it is also noted that there is a close association between teaching effectiveness or teaching ineffectiveness and teachers' competence [64]. It was further argued that teachers who are competent would provide conducive environments and climate as well as the enabling classroom conditions for effective students' learning. [63] argued that performance is a function of competence and therefore, teachers must possess the competence for better performance. In summary, competent teachers are those who have the ability to provide valuable outcomes without excessively costly behavior [70]. It is the teaching skill and ability possess by the teachers.

Based on the above discussion, we expect a constructive relationship of the compensation, competence, job motivation with teacher performance and propose the following hypotheses:

H1: The compensation positively influences job motivation.

$\mathrm{H} 2$ : The competence positively influences job motivation.

H3: The compensation positively influences teacher performance.

H4: The competence positively influences teacher performance.

H5: The job motivation positively influences teacher performance.

H6: The job motivation is positively mediate the relationship between compensation and teacher performance. 
H7: The job motivation is positively mediate the relationship between competence and teacher performance.

Figure 1. shows the conceptual framework of the study, developed based on the study of the literature. The frameworks consists three independent variables namely compensation, competence and job motivation, together with the relationship with the dependent variable which is teacher performance.

Fig. 1. The research frameworks

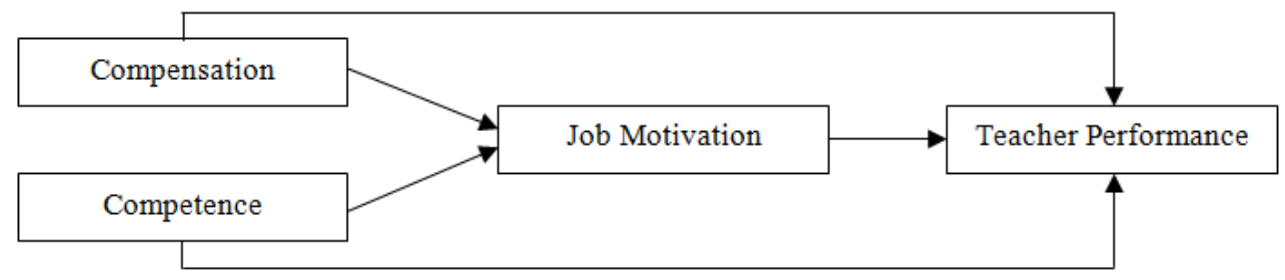

\section{METHODOLOGY}

\section{A. Respondents and research procedure}

Data were collected through a questionnaire that distributed to 351 teachers from seven senior high schools that made the object of research. In addition, supporting data is obtained from interviews with respondents.

\section{B. Data Analysis}

There are four variables studied which were compensation (X1), competence (X2), career commitment, job job motivation (Z), and teacher performance (Y). This data study was analyzed by Partial Least Square (PLS) through SEMPLS software with WarpPLS 3.0. This technique has powerful analytical tool because it does not assume the data should have certain measurement scale, a certain amount, and can be used to confirm theory [71].

The Partial Least Square (PLS) that has been used in this research is Warp software PLS. It was used to analyse the causal relationship between the variables of compensation, competence, job motivation and teacher performance in accordance with the hypothesis that has been proposed. PLS have two stages of analysis, namely the inner evaluation model (testing the construct validity and reliability) and outer evaluation model (testing the causal relationship between the magnitudes of the variables in the study).

\section{RESULTS AND DISCUSSION}

The part of measurement model evaluation included testing the validity and reliability of measurement instruments used in this study. Testing the validity of the PLS consists of two parts, namely the convergent validity and discriminant validity.

\section{A. Convergent Validity}

The first evaluation of the measurement model is convergent validity (convergent validity). To view the test results of convergent validity of the measurement instrument (questionnaire) can be seen in output combined loadings and cross loading. There are two criteria to assess whether the model qualifies outer convergent validity.

After the reduction of indicators that did not fit the criteria, it can be seen that the outer loading each of the indicators on the four research variables are all worth more than 0.40 with a p-value of less than 5\%. This means that the indicators used in this study has met convergent validity.

\section{B. Discriminant Validity}

The second evaluation on the outer model is discriminant validity. Measuring discriminant validity is done by using the value of cross loading. An indicator is said to meet the discriminant validity if the value of the cross loading indicator variable is the largest compared to other variables.

Based on the value of cross loading, it can be seen that all the indicators that make up each of the variables in this study meets discriminant validity because it has the largest crossloading for a variable to the establishment and not on other variables. Thus all of the indicators in each of the variables in this study have met the discriminant validity.

\section{Reliability Test}

Final evaluation on the outer model is a composite of reliability and Cronbach alpha. Composite reliability and Cronbach alpha reliability of the instrument test the value in a variable. A variable is said to meet the reliability test if it has a value of composite reliability and Cronbach alpha of greater than 0.7 . 
TABLE I. COMPOSITE ReLIABILITY AND CRONBACH ALPHA

\begin{tabular}{|c|c|c|c|}
\hline \multicolumn{4}{|c|}{ Composite reliability coefficients } \\
\hline Compensation (X1) & Competence (X2) & Job Motivation (Z) & Teacher Performance (Y) \\
\hline 0.902 & 0.932 & 0.926 & 0.947 \\
\hline \multicolumn{4}{|c|}{ Cronbach's alpha coefficients } \\
\hline Compensation (X1) & Competence (X2) & Job Motivation (Z) & Teacher Performance (Y) \\
\hline 0.884 & 0.914 & 0.911 & 0.932 \\
\hline
\end{tabular}

Table I showed that the value of reliability and Cronbach alpha compositing each study variable value greater than 0.7 . It can be concluded that each variable has met the composite reliability.

Evaluation of Structural Model Section inner evaluation includes an assessment of the model R-squared, Q-squared, the effect size, goodness of fit and test causality. Rated average path coefficient (APC) generated at 0.352 and significantly less than 5\%. Average value of R-Square (ARS) generated by 0.502 and significantly less than 5\%. Average value of variance inflation factor (AVIF) amounted to 1327 less than 5. Thus, it can be concluded that the goodness of fit of models have been met.

\section{Hypothesis testing}

Here is the Table of proof hypothesized relationship between the variables directly and indirectly (a relationship which sees the role of job motivation as an intervening variable):

TABLE II. COEFICIENT Estimate AND HyPOTHESIS SigNIFICANCE EVIDENCE

\begin{tabular}{|c|c|c|c|}
\hline \multicolumn{4}{|c|}{ Direct Effect } \\
\hline Path & Coefficient Estimate & Significant & Information \\
\hline $\mathrm{X} 1 \rightarrow \mathrm{Z}$ & 0.317 & 0.001 & Affect + significant \\
\hline $\mathrm{X} 2 \rightarrow \mathrm{Z}$ & 0.338 & 0.000 & Affect + significant \\
\hline $\mathrm{Z} \rightarrow \mathrm{Y}$ & 0.394 & 0.000 & Affect + significant \\
\hline $\mathrm{X} 1 \rightarrow \mathrm{Y}$ & 0.367 & 0.000 & Affect + significant \\
\hline $\mathrm{X} 2 \rightarrow \mathrm{Y}$ & 0.344 & 0.000 & Affect + significant \\
\hline \multicolumn{4}{|c|}{ Indirect Effect } \\
\hline Path & Coefficient Estimate & Significant & Information \\
\hline $\mathrm{X} 1 \rightarrow \mathrm{Z} \rightarrow \mathrm{Y}$ & 0.148 & 0.028 & Affect + significant through JM \\
\hline $\mathrm{X} 2 \rightarrow \mathrm{Z} \rightarrow \mathrm{Y}$ & 0.133 & 0.032 & Affect + significant through JM \\
\hline
\end{tabular}

The theoretical model on the conceptual framework of the study can be said fit if it supported by empirical data, as given in Figure 2 below.

Fig. 2. Analysis result of PLS

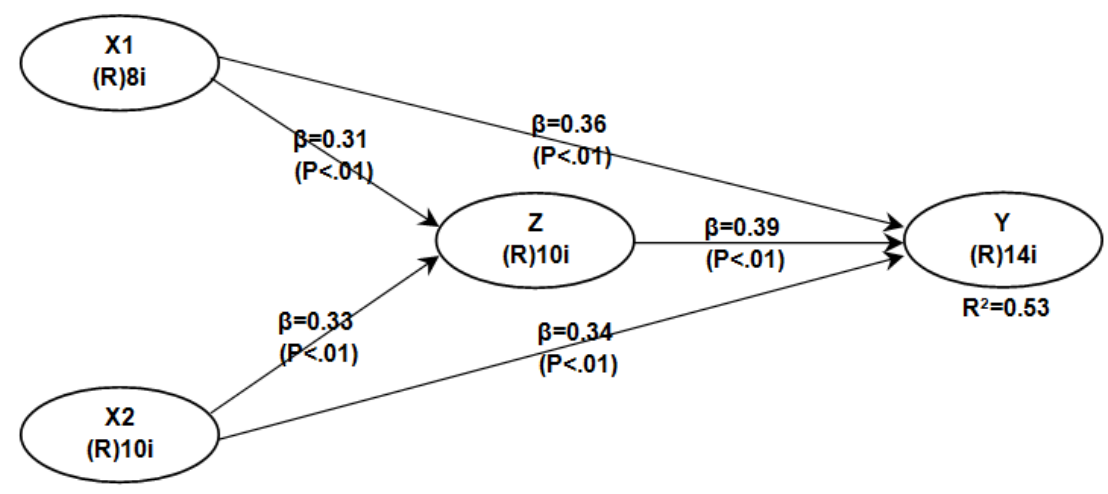

Path coefficient value of compensation affects job motivation at 0.317 with a p-value less than 0.001 it indicated that there was significant positive effect of compensation on job motivation of the Senior High Schools Teachers. That is, 
the increase in compensation will result in an increase in job motivation. Based on these results, the hypothesis of the research first suspected an influence compensation significantly to job motivation on Senior High Schools Teachers was accepted.

Path coefficient value of competence affects job motivation at 0.338 with a p-value less than 0.001 it indicated that there was significant positive effect of competence on job motivation of the Senior High Schools Teachers. That is, the increase in competence will result in an increase in job motivation. Based on these results, the hypothesis of the second studies indicated that a competence gave significant effect to job motivation on Senior High Schools Teachers was accepted.

Path coefficient value compensation affects teacher performance of 0.394 with a p-value of 0.001 which is less than $5 \%$, this indicated that there is a significant positive influence of compensation on the teacher performance. That is, the increase in compensation will result in an increase teacher performance. Based on these results, the hypothesis of the three studies alleging that there is significant influence to the compensation of teacher performance on Senior High Schools was acceptable.

The coefficient of path of competence influence teacher performance of 0.367 with a p-value of 0.000 which is less than $5 \%$, this showed that there was a significant positive influence of the competence on teacher performance. That is, the increase in competence will result in an increase in teacher performance. Based on these results, four of the study hypothesis suspected an competence significant influence of teacher performance on Senior High Schools, was acceptable.

Path coefficient value that job motivation affects teacher performance amounted to 0,344 with p-value of 0.000 which is less than $5 \%$, this indicated that there was a significant positive effect of job motivation on teacher performance. That is, an increase in job motivation will result in an increase in teacher performance. Based on these results, the hypothesis fifth suspect there are studies that influence job motivation, teacher performance significantly to the teachers Senior High Schools, is acceptable.

Job motivation on proven research as an intervening variable between compensation with teacher performance significant effect on job motivation and teacher performance. The results of the study indicate that the PLS on the path coefficient value of 0.148 with a p-value of 0.028 which is less than $5 \%$, this shows there is a significant indirect influence between the compensation with teacher performance on the Senior High Schools teachers.

Job motivation on proven research as an intervening variable between competence with teacher performance significant effect on job motivation and teacher performance. The results of the study indicate that the PLS on the path coefficient value of 0.133 with a p-value of 0.032 which is less than $5 \%$, this shows there is a significant indirect influence between the competence with teacher performance on the Senior High Schools teachers.

\section{CONCLUSIONS AND RECOMMENDATIONS}

Based on Partial Least Square (PLS) using PLS software WARP 3.0 can conclude that: The results show that compensation and competence are significantly influence toward job motivation. Results also showed that compensation, competence, and job motivation are significantly influence toward teacher performance. Meanwhile, job motivation support mediate the relationship between compensation and competence to senior high schools teacher performance in Lhokseumawe.

Based on the analysis, it is recommended as follows: a) advice to teachers in order to improve aspects of compensation that are supported with the satisfaction of a good work, will be able to improve the performance of teachers, b) advice to the principal in order to improve the competence, given the findings shows that the higher competence that are supported by job motivation, the better the performance of teachers. c) advice to policy makers, in order to carry out leadership training for principals on a regular basis, in order to improve school performance that is lead, control the competence of teachers periodically, in order to improve the skill and ability of the teachers in terms of teaching.

\section{References}

[1] Dessler, G. (2011). Human Resource management. (12 th ed.). PrenticeHall, USA.

[2] Campbell, J. P., Gasser, M. B., \& Oswald, F. L. (1996). The Subtantive nature of job performance variability. In K. R. Murphy (Ed.), Individual Differences and behavior in organizations (pp. 258-299). San Francisco: Jossey-Bass.

[3] Schmidt, F. L., \& Hunter, J. E. (1998). The validity and utility of selection methods in personnel psychology: Practical and theoretical implications of 85 years of research findings. Psychological Bulletin, $124,262-274$

[4] Schmitt, N., \& Chan, D. (1998). Personnel selection: A theoretical approach. Newbury Park, CA: Sage Publications.

[5] Yeo, G. B., \& Neal, A. (2004). A multilevel analysis of effort, practice, and performance: Effects of ability, conscientiousness, and goal orientation. Journal of Applied Psychology, 89, 231-247

[6] Egbo, B. (2011). Teacher capacity building and effective teaching and learning: a seamless connection. Mediterranean Journal of Social Sciences, 2 (5), 1-7.

[7] Motowidlo, S. J., Borman, W. C., \& Schmit, M.J. (1997). A theory of individual differences in task and contextual performance. Human Performance, 10, 71-83

[8] Delery, E.J., \& Doty, H.D. (1996). Modes of theorizing in strategic human resource management: Tests of universalistic, contingency, and configurational performance predictions. Academy of Management Journal, 39, 802-835.

[9] Van Scotter J.R., \& Motowildo, S.J. (1996). Interpersonal facilitation and job dedication as separate facets of contextual performance. Journal of Applied Psychology, 81, 525-531.

[10] Harrison, A. W., Rainer, R. K., Hochwarter, W. A., \& Thompson, K. R. (1997). Testing the self-efficacy performance linkage of social-cognitive theory. Journal of Social Psychology, 137 (1), 79-87.

[11] Hurtz, G., \& Donovan, J. (2000). Personality and job performance: The big five revisited. Journal of Applied Psychology, 85 (6), 869-879.

[12] Canty, L.T. (2005). Conceptual assessment: transformational, transactional and laissez-faire leadership styles and job performances of managers as perceived by their direct reports. (Doctoral dissertation). 
Retrieved from ProQuest Dissertations and Theses database. (AAT 3187790).

[13] Messer, T. L. (2007). A study on the General self-efficacy: training, job performance and attrition of novice army mechanics in a simulated work environment. (Doctoral dissertation). Retrieved from ProQuest Dissertations and Theses database. (AAT73247815).

[14] Sommer-Krause, D. L. (2007). Exploring the relationship of employee wellness and job performance. Capella University. (Doctoral dissertation). Retrieved from ProQuest Dissertations and Theses database. (AAT 3258752).

[15] Bowen, J., \& Ford, R. C. (2002). Managing service organisations: does having a "thing" make a difference? Journal of Management, 28 (3), 447- 469

[16] Bowen, D. E., \& Hallowell, R. (2002). Suppose we took service seriously? An introduction to the special issue. Academy of Management Executive, 16 (4), 69-72.

[17] Abdull Sukor Shaari. (2003). Hubungan motivasi, keupayaan mengajar dan komitmen kerja dengan prestasi kerja guru Bahasa Melayu Sekolah Menengah. Unpublished Doctoral dissertation, Universiti Utara Malaysia, Malaysia

[18] Andreu, R., Canas, L., de Juana, S., Manresa, E., \& Rienda, L., \& Tari, J. J. (2006). Quality performance assessment as a source of motivation for lecturers: A teaching network experience. Journal of Educational Management, 20, 73-82.

[19] Flowers, C. P., \& Hancock, D. R. (2003). An interview protocol and scoring rubric for evaluating teacher performance. Assessment in Education, 10, 162-168. Fowers \& Hancock, 2003)

[20] Azman bin Abbas. (2007). Hubungan keafiatan sekolah. Gelagat kewarganegaraan organizasasi dan keberkesanan sekolah. Unpublished doctoral dissertation, Universiti Utara Malaysia, Malaysia

[21] Somech, A., \& Ron, I. (2007). Promoting organizational citizenship behavior in schools: The impact of individual and organizational characteristics. Educational Administration Quarterly, 43, 38-66. Somech \& Ron, 2007

[22] Bogler, R. \& Somech, A. (2005). Organizational citizenship behavior in school: How does it relate to participation in decision making? Journal of Educational Administration, 43, 420-438

[23] Kraus, E. (2002). Personality and performance: The mediating roles of leader member exchange quality and action control. Florida International University, Miami.

[24] Van Emmerik, I. H., \& Euwema, M. C. (2007). Who is offering a helping hand? Associations between personality and OCBs, and the moderating role of team leader effectiveness. Journal of Managerial Psychology, 22, 530-548.

[25] Zeithaml, V.A., Parasuraman, A. \& Berry, L.L. (1990). Delivering Quality Service: Balancing Customer Perceptions and Expectations. New York, NY: Free Press.

[26] Nyquist, J.D., Bitner, M.J., \& Booms, B.H. (1985). Identifying communications difficulties in the service encounter: a critical incidents approach", in Czepiel, J., Solomon, M. and Surprenant, C. (Eds), The Service Encounter, Lexington Books, Lexington, MA, pp. 195-212.

[27] Hartline, M.D., \& Ferrell, O.C. (1996). The management of customercontact service employees: An empirical investigation. The Journal of Marketing, 60(4), 52-70.

[28] Spencer, L., \& Spencer, S. (1993). Competence at work: Models for superior performance. New York: John Wiley \& Sons, Inc.

[29] Vathanophas, V., \& Thai-ngam, J. (2007). Competency requirements for effective job performance in the thai public sector. Contemporary Management Research, 3 (1), 45-70.

[30] Vakola, M., Soderquist, K.E., \& Prastacos, G.P. (2007).Competency management in support of organisational change. International Journal of Manpower, 28 (3/4), 260-275

[31] Potluri, R. M., \& Zeleke, A.A. (2009). Evaluation of customer handling competencies of Ethiopian employees. African Journal of Business Management, 3 (4), 131-135.

[32] Deros, B.M., Yusof, S. M., \& Salleh, A. M., (2006). A benchmarking implementation framework for automotive manufacturing SMEs. Benchmarking: An International Journal, 13 (4), 396 - 430.
[33] Ahmad, N.H., Ramayah, T., Wilson, C., \& Kummerow. (2010).Is entrepreneurial competency and business success relationship contingent upon business environment? A study of Malaysian SMEs. International Journal of Entrepreneurial Behaviour \& Research, 16 (3), 182-203.

[34] Azmi, I.A.G. (2010). Competency-based human resource practices in Malaysian public sector organisations. African Journal of Business Management, 4 (2), 235-241

[35] Harden, R. M., \& Crosby, J. R. (2000). The good teacher is more than a lecturer - the twelve roles of the teacher. AMEE Education Guide No 20, Medical Teacher, 22 (4), 334-347.

[36] Al-Turki, U. \& Duffuaa, S. 2003, 'Performance measures for academic departments'. The International Journal of Educational Management, 17 (6/7), 330-338.

[37] Pritchard, R.D., Holling, H., Lammers, F., \& Clark, B.D. (2002). Improving organisational performance with the productivity measurement and enhancement system: An international collaboration, Nova Science, NewYork.

[38] Jermias, J., \& Setiawan, T. (2008). The moderating effects of hierarchy and control systems on the relationship between budgetary. The International Journal of Accounting, 43, 268-292.

[39] Chew, I. K., \& Sharma, B. (2005). The effects of culture and hrm practices on firm performance empirical evidence from singapore. International Journal of Manpower, 26 (6), 560-581.

[40] Mundarti, M. (2007).The Influence factors of lecturer performance in implementing teaching-learning process in Midwifery Study Program of Magelang -Semarang Health Polytechnic, academic year 2005/2006.Masters thesis, MIKM UNDIP.

[41] Fah, B.C.Y., \& Osman, S. (2011). A case study of student evaluation of teaching in university. International Education Studies, 4 (1), 44-50.

[42] Halim, Y.A. (2009). Development and validation of an instrument to access the lecturers' performance in the education and teaching duties.Jurnal Pendidikan Malaysia, 34 (2), 33 - 47.

[43] Lucky, I.O.E. (2011).Entrepreneurial performance and firm performance. Are they synonymous? A Ph.D. experience. International Journal of Business and Management Tomorrow, 1 (2), 1-6.

[44] Kalimullah et al (2010). Impact of Employees Motivation on Organizational Effectiveness. Business Management and Strategy, 3(1), $36-45$.

[45] Reena, A., \& Shakil, M.A. (2009). Factors Influencing Organizational Performance In Metro Specialist Hospital, Sungai Petani, Kedah Darul Aman. Master Thesis University Utara Malaysia.

[46] Muogbo, U. S. (2013). The Impact of Employee Motivation On Organisational Performance ( A Study Of Some Selected Firms In Anambra State Nigeria)

[47] Jesarati, A., Babazadeh, H., Zanjani, S., Jesarati, A., Azizi, H., Rezapur, A., \& Hashemi, J. (2013). An investigation of the relationship between motivational factors and performance of education staff, 3(3), 681-686.

[48] Chowdhury, M. S. (2007). Enhancing motivation and work performance of the salespeople : the impact of supervisors ' behavior. African Journal of Business Management, 1(9), 238-243.

[49] Whitley, R. (2002). Employee motivation and organizational performance, 5(1), 53-60. Review of Applied Socio- Economic Research (Volume 5, Issue 1/ 2013), pp. 53.

[50] Allen and Kilmann, (2001) The role of the reward system for a total quality management based strategy, Journal of Organizational Change Management, 14 (2), 110-131.

[51] Yap J.E, Bove L.L \& Beverland M.B (2009), Exploring the effects of different reward programs on in-role and extra-role performanceof retail sales associates, Baltic Journal of Management, 12 (3), 279-294

[52] Rotundo, M., \& Sackett, P.R. (2002). The relative importance of task, citizenship and counterproductive performance of global ratings of job performance: A policy capturing approach. Journal of Applied Psychology, 87, 66-80.

[53] Savelsbergh, C.M.J.H, Heijden, B.I.J. M. V. D and Poell, RF (2010), Attitudes towards factors influencing team performance. A multi-rater approach aimed at establishing the relative importance of team learning behaviors in comparison with other predictors of team performance, Team Performance Management, 16 (7/8), 451-474 
[54] Schmidt, Trittel and Muller (2011), Performance-related pay in German public services The example oflocal authorities in North RhineWestphalia, Employee Relations, 33 (2), 140-158

[55] Carraher (2011) Turnover prediction using attitudes towards benefits, pay, and pay satisfaction among employees and entrepreneurs in Estonia, Latvia, and Lithuania, Baltic Journal of Management, 6 (1), 2552.

[56] Allen and Kilmann, (2001) The role of the reward system for a total quality management based strategy, Journal of Organizational Change Management, 14(2), 110-131.

[57] Armstrong, Brown and Reilly (2011), Increasing the effectiveness of reward management: an evidence-based approach, Employee Relations, 33(2), 106-120

[58] Shanock, L.R., \& Eisenberger, R. (2006). When supervisors feel supported: Relationships with subordinates' perceived supervisor support, perceived organizational support, and performance. Journal of Applied Psychology, 91, 689-695.

[59] Chapman and Kelliher (2011), Influences on reward mix determination: reward consultants' perspectives, Employee Relations, 33 (2), 121-139

[60] Pashiardis, G. (2000). School climate in elementary and secondary schools: views of Cypriot principals and teachers. The International Journal of Educational Management, 14, 224-237.

[61] Scott-Ladd, B., Travaglione, A., \& Marshall, V. (2006). Causal inferences between participation in decision making, task attributes, work effort, rewards, job satisfaction and commitment. Leadership \& Organization Development Journal, 27, 400-414.
[62] Yusuf, A. (2007). Professionalizing teacher for the development of the education sector. Ilorin Journal of Education. 27

[63] Teodorescu, T. (2006). Competence versus competency what is the difference? International Society for Performance Improvement, 45 (10), 27-30.

[64] José Passos, A.F. (2009). A comparative analysis of teacher competence and its effect on pupil performance in upper primary schools in mozambique and other sacmeq countries. Ph.D. Thesis, University of Pretoria Pretoria.

[65] Teodorescu, T. (2006). Competence versus competency what is the difference? International Society for Performance Improvement, 45 (10), 27-30.Achwarin, N. A. (2007). The study of teacher competence of teachers at schools in the three southern provinces of thailand. Assumption University of Thailand.

[66] Westera, W. (2001). Competences in Education: a confusion of tongues. In Journal of Curriculum Studies,33(1), 75-88

[67] Schilling, J.F., \& Koetting, J.R. (2010). Underpinnings of competencybased education. Athl Train Education Journal, 5 (4),165-169.

[68] Sahan, A. (2009). Teacher's competence and students' achievement.Retrieved from http://anselsahang.blogspot.com/2009/02/teachers-competence.html.

[69] Gilbert, T.F. (1996). Human competence. Silver Spring, MD: International Society for Performance Improvement.

[70] Hair, J. F., Ringle, C. M., and Sarstedt, M. 2011. "PLS-SEM: Indeed a Silver Bullet," Journal of Marketing Theory and Practice (19:2), pp.139151 